\title{
TALLINN RADIOCARBON DATES IV
}

J M PUNNING, R RAJAMÄE,
M EHRENPREIS, and L SARV

Institute of Geology, Academy of Sciences, Estonian SSR

The following list includes samples dated in 1975. The measurement of ${ }^{14} \mathrm{C}$ activity was performed with 1-channel and 2-channel scintillation devices. Special attention was paid to the decrease of the background. The effectiveness of the measurement is ca 50\% (Punning, Rajamäe, 1975). The "enriched standard" (Alekseejev et al, 1971) has been used as a contemporary reference standard of modern carbon. Age calculations are based on the ${ }^{14} \mathrm{C}$ half-life of $5568 \pm 30 \mathrm{yr}$, with 1950 as the standard year of reference. All samples are calculated to $\pm 1 \sigma$ with respect to sample, standard and background after counting times of at least 2800 minutes. ${ }^{13} \mathrm{C} /{ }^{12} \mathrm{C}$ measurements and corrections have not been made for these samples.

\section{GEOLOGIC SAMPLES}

\section{A. Estonian SSR}

Tln-130. Lemmeoja

$9820 \pm 130$ 7870 BC

Wood peat from exposure on bank of Lemmeoja R, Pärnu Dist. Peat $45 \mathrm{~cm}$ thick underlies eolian sands and gravel containing shells of mollusks. Sample taken from upper part of peat. Coll 1974 and subm by H Kessel, Inst Geol, Acad Sci Estonian SSR (now Inst Geol).

\section{Tln-132. Koivasoo}

$6240 \pm 210$

4290 вC

Coarse detritic sapropel from Kõivasoo mire, I Hiiumaa. Mire formed after separation of near-shore lake from open sea by littoral deposits of $\mathrm{Hg}$ Littorino regression. Sample from depth 200 to $210 \mathrm{~cm}$. Coll 1974 and subm by H Kessel.

\section{Tln-131. Koivasoo}

$9565 \pm 120$

Lacustrine lime from Kõivasoo mire (see Tln-132). Sample from depth 220 to $230 \mathrm{~cm}$.

\section{TIn-134. Sindi}

$4975 \pm 100$

3025 BC

Buried sedge peat from profile on left bank of Pärnu R, Pärnu Dist. Peat buried under Littorina Sea medium-grained sands. Sample from depth 180 to $185 \mathrm{~cm}$. Coll 1974 and subm by H Kessel.

TIn-133. Sindi

$7215 \pm 90$

5265 вC

Buried reed peat from profile on left bank of Pärnu R (see Tln-134). Sample from depth 300 to $310 \mathrm{~cm}$. 


\section{Tln-135. Sojamäe}

$8915 \pm 90$

$6965 \mathrm{BC}$

Coarse detritic sapropel from Sõjamäe bog, Harju Dist. Lagoonal sediments of Yoldia Sea overlie moraine. Sample from depth 430 to $450 \mathrm{~cm}$. Coll 1974 and subm by $\mathrm{H}$ Kessel.

\section{Tln-178. Oara}

$5520 \pm 100$

3570 вC

Buried sedge and reed peat underlies Littorina Sea deposits, Pärnu Dist. Sample coll from upper part, 0 to $5 \mathrm{~cm}$, of organogenous layer, $95 \mathrm{~cm}$ thick. Pollen analysis by $\mathrm{H}$ Kessel refer peat to Pollen Zone AT2. Sample coll 1975 by J M Punning and R Vaikmäe.

\section{Tln-179. Oara}

Sapropel with aleuritic interlayers from lower part, 90 to $93 \mathrm{~cm}$, of organogenous layer. Pollen Zone AT1.

\section{B. Byelorussian SSR}

\section{Tln-136. Morino}

Peat with wood remains from bog-like sediments on right bank of Nieman R, $2 \mathrm{~km}$ downstream from v Morino, Grodno Dist. Alluvial deposits of lst terrace, $380 \mathrm{~cm}$ thick. Sample from depth 350 to $380 \mathrm{~cm}$. Coll 1974 and subm by L Voznyachuk, Inst Geochem \& Geophysics, Acad Sci Byelorussian SSR.

\section{Tln-137. Lateshi}

$10,870 \pm 100$

Peat from aleuritic complex in $5 \mathrm{~m}$ terrace on left bank of Niemen $\mathrm{R}$ near v Lateshi, Grodno Dist. Terrace underlies dunes 8 to $10 \mathrm{~m}$ high. Sample from depth 600 to $610 \mathrm{~cm}$. Coll 1974 and subm by L Voznyachuk.

\section{Tln-138. Gozha}

$23,850 \pm 300$

Plant remains from aleuritic complex on right bank of Nieman $R$ near v Gozha, Grodno Dist. Complex containing Dryas flora is embedded in alluvium in terrace 13 to $15 \mathrm{~m}$ high. Sample from depth 1250 to $1275 \mathrm{~cm}$. Coll 1974 and subm by L Voznyachuk.

\section{Tln-139. Plaskovchyi}

$24,050 \pm 450$

Plant remains from bog-lake sediments in aleuritic complex of buried terrace, 7 to $8 \mathrm{~m}$ high, on right bank of Niemen R, opposite $\mathrm{v}$ Plaskovchyi, Grodno Dist. Sample from depth 624 to $635 \mathrm{~cm}$. Coll 1974 and subm by $\mathrm{L}$ Voznyachuk.

\section{Tln-155. Gozhka}

$775 \pm 60$

Wood from 1st terrace at confluence of Gozhka $\mathrm{R}$ with Niemen $\mathrm{R}$, Grodno Dist. Sample from depth 277 to $305 \mathrm{~cm}$. Coll 1974 and subm by L Voznyachuk. 


\section{Tln-161. Novyi Sverzhen}

Peat from bog-lake sediments in alluvial complex of 1st terrace, ca $3 \mathrm{~m}$ high, on left bank of Niemen R near v Novyi Sverzhen, Grodno Dist. Sample from depth 230 to $250 \mathrm{~cm}$. Coll 1974 and subm by L Voznyachuk.

\section{TIn-163. Ogorodniki}

$\mathbf{3 8 2 0} \pm \mathbf{1 0 0}$

Peat from bog-lake sediments in alluvial complex of 1st terrace, ca $3 \mathrm{~m}$ high, on right bank of Niemen R near v Ogorodniki, Grodno Dist. Sample from depth 227 to $230 \mathrm{~cm}$. Coll 1974 and subm by L Voznyachuk.

\section{Chevakino series}

$$
\text { C. Arkhangelsk and Murmansk Districts }
$$

\section{Tln-127. Chevakino}

Buried peat with wood remains from ancient sea terrace on left bank of Severnaya Dvina R near v Chevakino. Arkhangelsk Dist. Peat, abundant in half-decayed wood remains, underlies fine-grained sands. Sample from depth 60 to $65 \mathrm{~cm}$. Coll 1974 and subm by B Koshechkin, Inst Geol, Kola Branch Acad Sci USSR.

\section{Tln-128. Chevakino}

$9060 \pm 110$

Buried peat from ancient sea terrace on left bank of Severnaya Dvina R (see Tln-127). Sample from depth 120 to $125 \mathrm{~cm}$. Coll 1974 and subm by B Koshechkin.

\section{Tln-129. Chevakino}

Buried peat from ancient sea terrace on left bank of Severnaya Dvina R (see Tln-127). Sample from depth 160 to $165 \mathrm{~cm}$. Coll 1974 and subm by B Koshechkin.

\section{Tln-159. Lovozerskaya tundra}

$$
29,020 \pm 550
$$

Plant remains from borehole in $\mathrm{N}$ part of Lovozerskaya tundra, Murmansk Dist. Lake-bog sediments $9 \mathrm{~m}$ thick are embedded between moraines. Samples from depth 1530 to $1640 \mathrm{~cm}$. Coll 1974 and subm by V Evzerov, Inst Geol, Kola Branch Acad Sci USSR.

\section{TIn-162. Lovozerskaya tundra} $\geqslant 30,000$

Wood twigs from same complex as Tln-159. Sample from depth 1530 to $1640 \mathrm{~cm}$. Coll 1974 and subm by V Evzerov.

$$
\text { D. West Spitzbergen (Svalbard) }
$$

Tln-145. Sveagruva

Shells from $22 \mathrm{~m}$ terrace on $\mathrm{N}$ coast of Van Mijen fiord, $2 \mathrm{~km} \mathrm{~W}$ of settlement Sveagruva. Coll 1974 by L Troitski, Inst Geog, Acad Sci USSR, and J M Punning. 


\section{Tln-146. Sveagruva}

$10,340 \pm 110$

Shells from $40 \mathrm{~m}$ terrace on $\mathrm{N}$ coast of Van Mijen fiord $2 \mathrm{~km} \mathrm{~W}$ of settlement Sveagruva. Sample at depth $8 \mathrm{~m}$ from surface of terrace. Coll 1974 by L Troitski and J M Punning.

\section{Dames-moraine series}

The so-called Dames-moraine represents a complex of glacial and glacial-marine deposits $8 \mathrm{~km}$ long, $1 \mathrm{~km}$ wide, and $40 \mathrm{~m}$ high on $\mathrm{N}$ coast of Van Mijen fiord. Dames-moraine is regarded as primary relief of glacial-marine accumulation (Semevskij \& Shkatov, 1965), result of 2nd abrasive distribution of surface of glacial-marine deposits (Troitsky, 1967), or an iceberg glacial-marine deposits (Lavrushin, 1969). Our data confirm that Dames-moraine is a complex of marginal deposits of Paula glacier. Sample coll 1974 by J M Punning and L Troitski.

\section{TIn-147. Dames-moraine}

$8555 \pm 90$

Shells from distal slope $5 \mathrm{~km}$ of from surface of deposits at height $40 \mathrm{~m}$.

TIn-148. Dames-moraine

Shells from distal slope ca $3 \mathrm{~km}$ W of settlement Sveagruva. Sample from surface.

\section{Tln-149. Dames-moraine}

$8150 \pm 90$

Shells from proximal slope at height $1 \mathrm{~m}$. $6200 \mathrm{BC}$ Sveagruva.

\section{Tln-150. Dames-moraine}

Driftwood from surface of distal slope.

\section{Tln-151. Dames-moraine}

Driftwood from surface in middle part.

\section{Tln-152. Dames-moraine}

Shells from surface ca height $32 \mathrm{~m}$ in middle part.

\section{Tln-160. Geiki-moraine}

$8405 \pm 90$

Shells from surface of Geiki-moraine near settlement Sveagruva. Sample at height $5 \mathrm{~m}$. Coll 1974 by J M Punning and L Troitski. 
Kiellströmdalen series

Tln-168. Kiellströmdalen

$9095 \pm 90$

Shells from surface of remnant sea terrace $25 \mathrm{~m}$ from river level on right bank of Kiellströmdalen $\mathrm{R}$ ca $15 \mathrm{~km} \mathrm{E}$ of settlement Sveagruva. Sample coll 1974 by J M Punning and L Troitski.

Tln-171. Kiellströmdalen

$8670 \pm 80$

Shells (Saxicava arctica) from remnant $15 \mathrm{~m}$ sea terrace (see Tln-168). Coll 1974 by J M Punning and L Troitski.

\section{TIn-187. Kiellströmdalen}

$8805 \pm 80$

Shells (Pecten islandicus) from same place as Tln-171.

$6855 \mathrm{BC}$

Tln-170. Rindersbukta

$6660 \pm 70$

$4710 \mathrm{BC}$

Shells washed out by streamlet from $80 \mathrm{~m}$ terrace on $\mathrm{E}$ coast of Rindersbukta, Van Mijen fiord. Sample coll 1974 by J M Punning and L Troitski.

Tln-157. Kapp Linne

$\geqslant 41,000$

Shells from exposure on right bank of Linne $\mathrm{R}$ ca $1.5 \mathrm{~km}$ downstream from lake Linne. Sample underlay moraine. Coll 1974 by J M Punning and $\mathrm{L}$ Troitski.

\section{Grön fiord series}

Tln-164. Grön fiord

$5160 \pm 90$

3210 BC

Shells from surface of $5 \mathrm{~m}$ terrace on W coast of Grön fiord opposite settlement Barentsburg. Coll 1974 by J M Punning and L Troitski.

Tln-165. Grön fiord

$\mathbf{8 8 3 0} \pm \mathbf{8 0}$

Shells from surface of $9 \mathrm{~m}$ terrace (see Tln-164).

$6880 \mathrm{BC}$

TIn-166. Grön fiord

$9355 \pm 80$

$7405 \mathrm{BC}$

Shells from surface of $20 \mathrm{~m}$ terrace (see Tln-164).

TIn-167. Grön fiord

$9840 \pm 90$

Shells from surface of $40 \mathrm{~m}$ terrace (see Tln-164.)

$7890 \mathrm{BC}$

Tln-172. Grön fiord moraine

$8000 \pm 70$

$6050 \mathrm{BC}$

Shells from dark gray loam near retreating margin of Grön fiord glacier. Sample coll 1974 and subm by L Troitski.

TIn-185. Grön fiord moraine

$3250 \pm 60$

1300 BC

Shells from W part of push moraine of Grön fiord glacier. Sample coll 1974 and subm by L Troitski. 
Tln-169. Sassendalen

$8660 \pm 70$

$6710 \mathrm{BC}$

Shells from $40 \mathrm{~m}$ terrace in valley Sassendalen. Age dated by outer layer (10 to $50 \%$ ). Sample coll 1974 and subm by L Troitski.

Tln-169A. Sassendalen

$8770 \pm 100$

Same as Tln-169. Age dated by inner layer.

$6820 \mathrm{BC}$

\section{Renarodden series}

TIn-173. Renarodden

$8150 \pm 70$

$6200 \mathrm{BC}$

Shells at depth $7 \mathrm{~m}$ from surface of $30 \mathrm{~m}$ terrace, cape Renarodden, Bellsund. Sample from contact of shingle and fine-grained loam. Coll 1974 and subm by L Troitski.

Tln-174. Renarodden

$9930 \pm 70$

7980 вC

Shells at depth $5 \mathrm{~m}$ from surface of $30 \mathrm{~m}$ terrace, cape Renarodden, Bellsund. Sample from right part of exposure. Coll 1974 and subm by L Troitski.

\section{TIn-175. Renarodden}

$30,750 \pm 800$

Shells from marine deposits in $30 \mathrm{~m}$ terrace, cape Renarodden, Bellsund. Coll 1974 and subm by L Troitski.

Tln-186. Brögger

$9970 \pm 80$

8020 BC

Shells at depth $3 \mathrm{~m}$ from surface of $25 \mathrm{~m}$ terrace, $4 \mathrm{~km} \mathrm{~W}$ of settlement Ny-Alesund. Coll 1975 and subm by L Troitski.

$$
\text { II. ARCHAEOLOGIC SAMPLES }
$$

\section{Laossina series}

\section{Estonian SSR}

Tln-158. Laossina

Charcoal from burial mound in Laossina, Põlva Dist. Estimated archaeol age: end of 1st millennium AD. Coll 1974 and subm by M Aun, Inst Hist, Acad Sci Estonian SSR (now Inst Hist).

Tln-180. Laossina

$$
1140 \pm 80
$$

Charcoal from burial mound in v Laossina. Coll 1974 from depth $84 \mathrm{~cm}$ and subm by M Aun.

TIn-184. Laossina

$$
460 \pm 80
$$

Charcoal from burial mound in v Laossina. Coll 1974 from depth $25 \mathrm{~cm}$ and subm by M Aun. 
Lohu series

Tln-181. Lohu

AD 1140

Charcoal from buried wall of stronghold Lohu on W bank of Keila R, Rapla Dist. Estimated archaeol age: 11th century. Sample coll 1974 and subm by $\mathrm{E}$ Tõnisson, Inst Hist.

\section{Tln-182. Lohu}

Charcoal from same complex as Tln-181.

\section{Tln-183. Lohu}

Charcoal from same complex as Tln-181.
AD 1140

$810 \pm 60$

$790 \pm 60$

AD 1160

$1680 \pm 60$

AD 270

\section{Tln-190. Pajumoisa}

Charcoal from stone grave on I Saaremaa. Estimated archaeol age: 5th century. Coll 1975 from depth 75 to $78 \mathrm{~cm}$ and subm by T Tamla, Inst Hist.

\section{TIn-191. Pajumoisa}

Charcoal from stone grave on I Saaremaa. Coll 1975 from depth 70 to $75 \mathrm{~cm}$ and subm by $\mathrm{T}$ Tamla.

\section{REFERENCES}

Alekseejev, V A, Vinogradova, S N, Galimov, E M, Lavrukhina, A K, Sulerzhidski, L D, and Forova, V S, 1971, Carbon isotopes in the rings of sequoia: All-Union conf on variations of radiocarbon content in the Earth's atmosphere and radiocarbon dating, Vilnius (in Russian).

Lavrushin, Yu A, 1969, Quaternary deposits of Spitzbergen: Moscow, Nauka (in Russian).

Troitski, L N, 1967, Glaciogeomorphological studies on Spitzbergen: Glaciological studies, v 13, p 108-124 (in Russian).

Punning, J M and Rajamae R, 1975, Some ways of background lowering in a liquid scintillation beta-spectrometer: Internatl conf in low radioactivity measurement and applications, abs, p 18-19.

Semevski, D V and Shkatov, E P, 1965, Contemporary regression of glaciers on Spitzbergen: Leningrad, p 179-191 (in Russian). 